\title{
Strategic Coalitions and Agenda-Setting in Fragmented Congresses: How the PRI Sets the Legislative Agenda in
}

\section{Mexico*}

\author{
Robert D. Knight \\ Chadron State College, Chadron, Nebraska, United States
}

\begin{abstract}
This essay suggests a theory of strategic legislative agenda control. It argues that a single party can effectively set the agenda under majoritarian gatekeeping rules without obtaining majority or even plurality status. The agenda-setting party need not be the median party in the assembly nor supported by executive-led parliamentary coalitions. The Mexican Chamber of Deputies provides a case study of how majoritarian gatekeeping and political context establish the conditions necessary for one-party-led agenda-setting in a fragmented congress with or without enduring coalitions. The failure of opposition coalitions to roll the 'Partido Revolucionario Institucional' evinces that party's ability to set the agenda through strategic coalition formation since 2000. High levels of party unity combined with strategic positioning have allowed the PRI to do so. The strategic nature of the PRI's coalitionmaking is documented and analyzed in the context of its historically pragmatic approach to coalition-making. The argument is supported by roll-call data analysis, using WNOMINATE, WRice scores, and roll rates.
\end{abstract}

Keywords: Legislatures; coalitions; agenda-setting; Mexico; WNOMINATE. 
genda-setting in legislative assemblies is important for two reasons.
First, the legislative process tends toward gridlock without institutions to limit and sequence the agenda (COX, 2006). Second, how the agenda is managed and by whom shapes legislative outcomes. A concern with gridlock is evident in the literature on Latin American legislatures. Juan Linz (1990) argued that multiparty presidential democracies are prone to failure because they lack incentives to form coalitions. Coalition formation and agenda-setting are related processes. Successful coalitions are supported by managing the legislative agenda to foster plenary success.

This investigation contributes to the literature on agenda-setting in fragmented (no majority party) legislative assemblies in presidential regimes. The Mexican Chamber of Deputies offers a case study in which one party has dominated agenda-setting, forming winning majority coalitions. Consequently, that party has the greatest influence over the content of legislation. Interestingly, this agenda setter is the same party that ruled Mexico from 1929 to 1997, when it lost its majority in the Chamber; namely, the Partido Revolucionario Institucional (PRI). This is the case despite the absence of favorable assembly rules, with or without a co-partisan executive, and whether its legislative faction held even a plurality of the seats. Furthermore, the party's control of the agenda has been exercised irrespective of its programmatic location relative to other parties in the assembly.

To understand how the PRI has set the agenda starting with the Fox 'sexenio' (six-year presidential term) in 2000, we will proceed as follows. First, we will review the literature on agenda-setting in multiparty presidential regimes. The review will show that existing theories do not explain the Mexican case. Second, a theory of strategic agenda-setting will be suggested based on intra-party programmatic constraints and strategic flexibility. Third, legislative institutions in Mexico are reviewed. Fourth, the methods used to analyze agenda-setting and coalition formation will be discussed. Fifth, the empirical results will be presented, showing how the PRI has consistently set the agenda. Sixth, these findings will be discussed considering the theory of strategic agenda setting. It will be argued that strategic positioning by the PRI along with programmatic constraints among its most significant rivals has allowed the PRI to set the agenda despite institutional 
and other contextual factors that do not advantage the party. Finally, the implications for theories of legislative agenda-setting will be considered.

\section{Theories of agenda-setting in fragmented congresses}

Existing theories of agenda control in fragmented legislatures cannot explain the Mexican case. They point to restrictive chamber rules favoring the plurality party, legislative coalitions, the role of the executive, and median parties to explain agenda setting. While the Mexican Chamber is not an 'open-sky' legislature, assembly rules do not favor the plurality party, and enduring majority coalitions have not been the norm. The majority controls the agenda, but no party has constituted a majority since 1997. Furthermore, Mexican presidents have little agenda setting powers, and make little use of their ability to assign portfolios to opposition parties. Finally, the median party has not consistently set the agenda. Nevertheless, the PRI has been the agenda setter since the seating of the LVIII Congress in the fall of 2000.

Common to the theories referenced above is the importance of legislative delegation and party unity. Central to Cox and McCubbins' $(1993,2005)$ seminal studies of agenda setting in the U.S. Congress are legislators' collective dilemmas and the resulting delegation of agenda powers to party leadership. Legislators delegate power to their party leadership to achieve legislative success. Leaders have a minimal fiduciary responsibility to ensure that bills opposed by most of their party are not passed on the floor. A critical question concerns the circumstances under which the rank and file is willing to make such a delegation. While Aldrich and Rodhe (2001) argue that delegation is conditional on party unity, Cox and McCubbins (2005) contend that legislators always find it in their interest to delegate negative agenda power. When there exists homogeneity of preferences, positive agenda powers are delegated.

While theories of agenda control based on the U.S. Congress have provided a theoretical framework, studies of agenda control in multiparty, fragmented congresses have raised additional issues. Agenda control in such legislatures necessitates coalitions or plurality empowering rules. Thus, the literature on agenda setting in such regimes has focused on how such coalitions are formed and how institutional rules have facilitated the agenda-setting process. The former 
question has focused on two issues. First, the importance of the median party. Second, the role of the executive in fostering legislative coalitions.

The importance of the median party for agenda setting is evident in Alemán's (2006) study of agenda control in Argentina, Chile, and Mexico. He explains the PRI's success in setting the agenda in Mexico in the absence of presidential agenda powers and empowering chamber rules by its centrist ideology, as well as its exceptionally high levels of party unity. He observes, "Ironically, losing the presidency gave the PRI a positional advantage as the median party in Congress" (ALEMÁN, 2006, p. 146). But in Chile and Argentina, presidents have been able to use their agenda powers to help their legislative coalition set the agenda. The importance of the executive in legislative agenda setting is also evident in Amorim Neto, Cox, and McCubbins' (2003) study of agenda setting in Brazil. These authors identify 'parliamentary agenda cartels' through portfolio assignments in the president's cabinet. Jones and Hwang (2005) argue that the PJ in Argentina has managed to control the agenda by forming coalitions with minor parties, thus marginalizing the UCR. Their analysis focuses on legislative agenda setting without the executive playing a central role.

Calvo's (2014) study of agenda setting in Argentina highlights the importance of chamber rules. He argues that those rules have facilitated agenda setting by the plurality party in the lower chamber. Under majority-party rule, policy outcomes move closer to the median legislator of the majority party. When no majority exists, outcomes reside in a space between the minority and plurality parties. While the plurality party's agenda setting powers are less substantial, they still shape legislative outcomes. Calvo (2014) compares the Argentine and Uruguayan legislatures, demonstrating that the latter's 'open sky' rules result in median outcomes.

Another important issue in the literature concerns measurement of agenda control. Cox and McCubbins (2005) employ roll rates and policy direction to estimate agenda control effectiveness (explained later in more detail). Amorin Neto et al. (2003) employ roll rates measured by parliamentary agenda cartels. They hypothesize that such coalitions should not be rolled more than five percent of the time. Roll rates should not form a U-shaped pattern since rolls will be skewed toward non-coalition members. During the last two years of the Cardoso 
administration a parliamentary agenda cartel existed. Calvo (2014) utilizes policy direction to assess control of the agenda.

\section{Strategic agenda-setting}

Spatial voting theory predicts that legislative outcomes will reflect the programmatic preferences of the chamber's median legislator given majoritarian assembly rules, open access to the floor, weak party unity, and the absence of external players, an autonomous legislative assembly. Cox and McCubbins' (2005) 'procedural cartel' theory predicts that the majority party will use its agendasetting powers to avoid rolls, resulting in non-median legislative outcomes.

The logic of legislative action becomes more complex when we attempt to develop theories of agenda control in fragmented congresses. Absent enduring 1 coalitions or chamber rules empowering a plurality party to set the agenda in an autonomous assembly, legislative outcomes should reflect median-party preferences given sufficient party unity. However, if 'open skies' rules give minorities unlimited access to the floor, the median legislator sets the agenda (COX and McCUBBINS, 2011). Unlimited legislative initiatives will undermine party unity. But given majoritarian gatekeeping rules, a unified median party will be able to set the agenda. It could do so through issue by issue (ad hoc) coalitions with parties to its left and right to maximize its own legislative preferences.

There is no reason to assume that enduring coalitions cannot develop in fragmented assemblies with majoritarian gatekeeping rules. Any group of parties may set the agenda by forming a majority coalition. Such a coalition need not revolve around the median party. One hundred percent of coalition members less one may be left or right of the median legislator. The coalition's dominant party may be at the extreme of the programmatic spectrum. In sum, where party unity facilitates coalition-making, we may see coalitions led by the median party. In that case, we should see legislative outcomes close to the median legislator of the median party, as well as the fewest rolls for the median party. Alternatively, we may observe enduring coalitions on the programmatic left or right resulting in

\footnotetext{
${ }^{1}$ Enduring coalition' indicates a pattern of legislative parties voting together across a range of legislative proposals.
} 
legislative outcomes further from the median legislator, and party rolls concentrated among parties outside of the majority coalition.

Given that more than one coalitional outcome is theoretically possible, some obvious questions arise in respect to fragmented, autonomous legislative assemblies operating under majoritarian gatekeeping rules. Under what conditions should we expect median-party-led coalitions instead of non-median-party-led coalitions? When should we expect ad hoc rather than enduring coalitions? Does one party tend to control the agenda more successfully across congresses than other parties? How does it do so? Unless we answer these questions, we do not have a complete theory of agenda-setting for fragmented congresses.

Legislators are rational actors that attempt to shape legislative dynamics in their favor. In their efforts to succeed, legislators must balance programmatic preferences with their desire to control the agenda and win on the floor ${ }^{2}$. Thus, strategy necessarily becomes part of a theory of legislative agenda-setting. Strategy is shaped by the character and resources of the actors. A legislative faction that places a higher value on success than on ideological consistency will be more capable of programmatically positioning itself to set the agenda than its competitors. Such a party will have more flexibility to position itself as the key majority-coalition partner. This is especially applicable in a fragmented, autonomous assembly under majoritarian gatekeeping rules since neither the rules nor external actors advantage one legislative party over another.

The most strategic party can set the agenda either as the median party forming ad hoc coalitions or by forming enduring majority-coalitions encompassing the median legislator as long as sufficiently high levels of party unity are maintained to ensure success. In the latter case, strategic legislative behavior is pursued in one of two ways. The lead coalition partner positions itself so that it is the most attractive alternative to one or more parties with similar preferences that will constitute a majority. The coalitional leader need not be in the programmatic center of the majority coalition. It simply needs to be closer to its junior partners than other parties with sufficient seats and party unity. The second method is side

\footnotetext{
${ }^{2}$ A fully developed theory of agenda setting would theorize the preferences of legislators and legislative leaders, as well as the relationship between them. This is beyond the scope of this study. The argument presented here is based on the logic of delegation and the motivations of legislative leaders fully developed by Cox and McCubbins (2005).
} 
payments, which have the effect of moving preferences closer to the lead coalition party. In sum, both institutional context and strategy matter in setting the agenda. Given the context, strategy makes a difference for agenda setting and shapes outcomes.

This study advances the hypothesis that the legislative party most willing and able to position itself strategically along the programmatic spectrum will form majority coalitions to control the legislative agenda. The institutional context of majority gatekeeping in a fragmented congress frames the applicability of this hypothesis. We cannot test this hypothesis with a single case study with little variation in the dependent variable, party control of the legislative agenda. Therefore, the following analysis seeks to illustrate the utility of this hypothesis for understanding legislative politics in Mexico's majoritarian assembly.

\section{The institutional context of Mexican legislative politics}

The theory of strategic agenda control presented above is limited to certain institutional contexts: majoritarian gatekeeping, high levels of party unity, leaders empowered to set the agenda in pursuit of legislative success, and an autonomous chamber. Furthermore, the theory assumes a party system in which some parties are more programmatically flexible than others. We review here the institutional context of legislative politics in Mexico.

Mexico's Chamber of Deputies empowers the majority to control access to the floor. The Chamber's rules do not advantage the plurality party. The Organic Law of Congress requires strict proportionality in the distribution of seats on the three leadership bodies that set the agenda (ALARCÓN OLGUÍN, 2009, p. 201). Formally, the agenda is set by the 'Conferencia'. However, the 'coordinadores' (legislative party leaders) on the 'Junta de Coordinación Política' sit in the 'Conferencia' where voting is again proportional to party seat share. Thus, the 'coordinadores' who represent a majority of seats exercise agenda-setting through the 'Conferencia' and its permanent body, the 'Mesa Directiva'. The 'comisiones ordinarias' (standing committees) are also agenda setters (LANGSTON, 2017, pp. 177-197: Ch. 9). They decide which bills and amendments will be submitted to the floor, subject to the discharge powers exercised by the 'Junta and the Mesa'. The 'Conferencia' sets the deadlines for reporting 'dictámenes' (bills with proposed 
amendments)(GONZÁLEZ, 2007). 'Dictámenes' are reported to the floor by majority vote in committees that usually reflect the coalitional majority in the 'Conferencia' and the 'Junta'. The procedural majority in the 'Junta' appoints its own party members to the most important committees. The 'coordinadores' have the power to replace committee members without constraints, including chairs (LEHOUCQ et al., 2008).

Majority coalition leaders are empowered to set the agenda. Formally, the party 'coordinador/a' is selected by the party's legislative faction and subject to replacement by the same. However, each party's central committee (CEN) has considerable influence over the selection of legislative party leaders, despite the practice of holding elections for factional leaders since 1997 (CAMP, 2007). Lehoucq et al. (2008) argue that the party's CEN selects the party's 'coordinador/a' prior to caucus elections. Nacif (2002) concurs and notes that the PRI legislative contingent sometimes dispenses with the ritual of elections. Béjar Algazi (2006) argues that democratic rules and values do not exist within the legislative factions. Langston (2017) observes that "the [Junta] determines which legislative bill will make it out of committee and which will remain in the 'freezer'"( LANGSTON, 2007, p. 191). In sum, while no party is advantaged over another by the rules, the majority coalition controls access to the floor through its leadership, which has been delegated considerable power.

An executive agenda-setting role complicates the theory presented above. Of course, executives do influence legislative behavior everywhere. That said, it is reasonable to assume an autonomous chamber for the analysis that follows. Mexican presidents since 2000 have included members of opposition parties in their cabinets, but most of them have been technocrats rather than influential politicians (CAMP, 2013). Of the 20 cabinet ministers in the Calderón administration, only 05 were politicians, all members of the President's party, the Partido Acción Nacional (PAN). There were 16 politicians in the 21-member Peña Nieto Cabinet, 13 from the President's party, the PRI, 02 from the Partido Verde Ecologista Mexicana (PVEM), and 01 from the Partido de la Revolución Democrática (PRD) ${ }^{3}$. While there were two 'panistas', they were both technocrats.

3 Figures are based on the author's review of biographies published at <https://www.gob.mx/presidencia/> as of March, 2014. 
The PAN has been the PRI's principle coalition partner during the Peña Nieto administration. If the President assigned portfolios to build parliamentary coalitions, one would expect PAN politicians in the cabinet. That said, posts held by the small but reliable PRI coalition partner, the PVEM, are likely an effort at building a parliamentary coalition.

The extent to which legislative parties are programmatically flexible matters for coalition-making. The nature of internal party divisions is important for evaluating the programmatic rigidity of parties. Mexican political parties are organizationally centralized, and at the same time internally factious (NACIF, 2002). The PRI's two main rivals present coherent, programmatic brands despite profound internal differences. The PRD has a clear leftist brand. It started as a break-away party from the PRI, exposing economic nationalism as the 'true' party of the Revolution (BRUHN, 1998). However, the party is divided over the question of movement versus institutional politics (MOSSIGE, 2013). As Bruhn (2015) observes, "The PRD's famously contentious internal politics have led its own members to refer to it as the party of tribes" (BRUHN, 2015, p. 70). Consequently, PRD deputies stress the freedom to vote one's conscience on the floor ${ }^{4}$. Nevertheless, the PRD "projects a consistent ideological signal" (CANTÚ and DESPOSATO, 2012, p. 12).

The same may be said for the center-right PAN. Wuhs (2013) writes that "as the party has staked out more particular positions on [social] and other issues, its place as a conservative Catholic party has grown increasingly clear" (WUHS, 2013 , p. 200). Leadership places considerable pressure on its deputies to conform to the party's legislative program ${ }^{5}$. Adherence to core principles is expected of PAN members despite significant internal divisions. Divisions are often centered around leadership contests and strategy. Wuhs (2001) argues that the main source of 'fractionalism' is the competition between the newcomer 'barbarians' and the 'bluebloods' over control of party resources. Still, divisions between traditionalist, who stressed ideological purity, and 'neopanists', who are more pragmatic, are prominent. These divisions are manifested in whether party leaders view the PAN

4 Statement based on in-person interviews with PRD deputies in 2006 and 2017.

5 Statement based on in-person interviews with PAN deputies in 2006 and 2017. 
as an ideological or a catchall party (LOAEZA, 2002). Mizrahi (2003) argues that the PAN's failure to transition to a catchall party has inhibited its ability to govern.

The PRI has traditionally been less programmatic. In discussing the party's participation in the 'Pacto', Camp (2016) notes "the PRI's characteristic preference for pragmatism over ideological stances of any kind..." (CAMP, 2016, p. 227). Cantú and Desposato (2012) note that "the PAN and the PRD are both more ideological than the PRI, and that the PRI is ideologically diverse and relies more on clientelism and distributive politics" (CANTÚ and DESPOSATO, 2012, p. 12). The party of the old hegemonic regime (1929 to 1997) brought elites under one umbrella to peacefully resolve the revolutionary elites' prisoners' dilemma; namely, how to ensure that competing politicians seeking rents would not use violence (defect) but rather resolve their differences peacefully (cooperate) (HABER et al., 2008). The party succeeded quite well in bringing together a heterogeneous group of politicians, as well as various key interest groups. Its creed was summed up as 'revolutionary nationalism'; branding that fits its ideological diversity well. The PRI is not only more ideologically diverse, it also has a more ambiguous party brand.

The PRI's loss of its legislative majority in 1997 resulted in a resurgence of the conflict between modernizers and traditionalists (CAMP, 2007, p. 236). By 2000 , the 'neoliberal' or modernizing wing of the party had lost support. The 'dinosaurios' or traditionalist wing found new energy following the party's defeat in the 2000 presidential election (WISE, 2003, pp. 188-189). Prud'homme (2010) writes that the party's leaders "positioned the PRI at the center of the political spectrum and pragmatically benefitted the state that they govern" (PRUD'HOMME, 2010, p. 63). Eventually, the PRI returned to neoliberal economic policies. For example, delegates to the party's 2014 national assembly unanimously voted to eliminate the bylaws proscribing the liberalization of the energy sector despite considerable opposition to doing so among many party members (CAMP, 2016, p. 224).

Diversity still exists within the PRI. The incredibly high levels of floor-voting party unity do not reflect ideological cohesion. Negotiations within the party are surely important to fostering floor-voting unity, as is party discipline. The PRI has a history of behind-the-scenes politicking, while projecting public unity. It also has 
a tradition of careerism within the party, combined with electoral and chamber rules that empower leadership to discipline their legislators. But to explain PRI unity solely in terms of careerism and discipline would be incomplete. Traditionally, the PRI has placed more value on legislative success than ideological coherence. A political party that has succeeded most of the time over many decades in keeping a diverse coalition together has the flexibility and floor-voting unity to strategically negotiate coalitions by which it sets the agenda. Domínguez (2015) opines that the "PRI rebuilt its cohesion thanks to its already noted skills in pragmatic negotiation. Principles need not matter. Victory does" (DOMÍNGUEZ, 2015, p. 277). The PRI's rivals in the Chamber are less programmatically flexible due to more coherent ideologies despite equally salient internal divisions. Programmatic heterogeneity is more likely to fracture the PRI's rivals than the PRI. The PRI has used this asymmetry to its advantage well.

\section{Measuring coalitions and agenda-setting}

\section{Wnominate}

To estimate the relative left-right programmatic locations of legislative parties, we will use WNOMINATE with a database of all roll-call votes in the Chamber of Deputies since $1998^{6}$. This statistic is a non-parametric scaling technique developed by Poole and Rosenthal (1991; also see POOLE, 2005). It is calculated using the WNOMINATE Package for the R statistics program (POOLE et al., 2011). WNOMINATE measures the distribution of voting preferences within and between parties. It identifies legislators' 'ideal points' along two spatial dimensions. The significance of the second dimension is assessed using Scree plots (displayed as supplemental graphs online at the BPSR website). Curves with 'sharp elbows' indicate a lack of significance for the second dimension. The 'ideal points' of deputies are displayed as coordinate plots in which each deputy's party affiliation is indicated.

\footnotetext{
${ }^{6}$ This study covers the LVII Congress (1997-2000) through the LXIII Congress (20152018). However, the dataset begins in 1998 when the Chamber of Deputies first started recording roll-call votes. The dataset goes halfway through the LXIII Congress; i.e., through 2016. Roll-call data from the LVII Congress was provide by John Carey (https://sites.dartmouth.edu/jcarey/data-archive/). All other roll-call data was entered by the author and his research assistants with the generous financial assistance of the CSC Research Foundation.
} 
WNOMINATE does not estimate the 'true' programmatic preferences of deputies (SAIEGH, 2009). This would only be the case if legislators were unconstrained in their roll-call choices, voted sincerely based on policy preferences, and all possible policy alternatives were on the agenda. Rather, the ideal points reflect actual voting decisions, which result from some combination of constraints (e.g., party discipline) and preferences (e.g., policy goals, career advancement), as well as the choices available. Agenda-setting limits the choices of legislators, as does party discipline. As noted by Carroll and Poole (2014), "where strategic voting is widespread ... one cannot assume that the variation in the data can be reasonably interpreted as reflecting the preferences of individual legislators" (CARROLL and POOLE, 2014, p. 116).

Determining the directionality of the programmatic left-right spectrum using WNOMINATE reflects the qualitative judgment of the analyst. While firstdimension determinations are usually unproblematic, second-dimension assignments of a party on the programmatic spectrum can be problematic. This dimension often has no apparent coherence other than an assortment of issues for which a different coalition of parties coalesced. We cannot use this statistic to estimate the distances between deputies due to the very high levels of party unity in the Mexican Chamber. Nor can we use a non-parametric statistic to compare programmatic locations across congresses. WNOMINATE does allow us to estimate how legislative parties compare in their vote choices. We will also be able to assess the dimensionality of legislative choice. A second dimension is observed when a different coalition of legislators regularly votes together for some types of legislative proposals as opposed to others. With high levels of party unity, a significant second dimension identifies a different coalition of parties.

Ideal points will be used to estimate whether the passage of new bills moves policy closer to the agenda-setting party. This is done using the technique developed by Cox and McCubbins (2005, pp. 65-68). Vote choice will be regressed (using Probit) on dimension 01 'or' dimension 02 ideal points depending on whether a roll-call vote scales as a first or second dimension one. The sign of each coefficient will be noted for all significant coefficients in each dimension, if the second dimension is significant in the congress. If the agenda setter is located to the right of the median legislator, then most of those coefficients should be 
positive, and vice versa. The total number of positive signs will be tabulated, then divided by the total votes to ascertain a percentage of roll-call votes that moved policy outcomes closer to the agenda-setting party.

To determine if a roll-call vote scales along the first or second dimension, vote choice is sequentially regressed on dimension 01 'and' 02 ideal points. The Pseudo R2 value is recorded for each binominal regression for each roll-call vote. If the first dimension R2 value is greater than the second dimension R2 value, then the roll-call vote is a first-dimension vote, and vice versa. Identifying the roll-call votes that scale along each dimension will be important to analyzing the types of coalitions and estimating if policy is moving in the direction of the agenda-setting party.

\section{WRICE statistic}

The WRice statistic will be used to estimate party unity scores on roll-call votes. Rice calculates party unity on a scale of zero to one. If party members vote with their party only half the time, the party's Rice score would be zero. If they vote with their party all the time, the party would have a Rice score of 01 , while voting with their party three-quarters of the time would result in a score of .50. A party"s Rice score is generated when we sum the absolute differential for a series of votes

$$
\left(\sum \mid \% \text { yeas - \%nays } \mid\right) \text {. }
$$

Carey's (2007) WRice statistic weights Rice for the closeness of the rollcall vote using the following formula.

$$
\operatorname{WRICE}_{i}=\sum \operatorname{RICE}_{\mathrm{ij}} * \operatorname{CLOSE}_{j} / \sum \operatorname{CLOSE}_{j}
$$

(where $i=$ the $i$ th party, $j=$ the $j$ th vote, and where CLOSE $j=1-(1 /$ THRESHOLD * |THRESOLD - \% YEA|)

The closeness of the vote is weighted on the assumption that party unity is more important for close votes than for ones that essentially are not contested. WRice scores are generated in STATA using a script written by John Cary

${ }^{7}$ Available at http://sites.dartmouth.edu/jcarey/legislative-voting-data/. 


\section{Descriptive statistics}

Descriptive statistics are used to determine the number and variety of coalitions formed during each congress among all possible majority coalition partners. This includes coalitions among potential partners with sufficient seats needed to win on the floor. Parties exceeding a minimum majority coalition are not counted in calculating potential winning coalitions. Frequencies of such coalitions are calculated for contentious roll-call votes, along with success rates. Contentious votes are those in which one of the three major parties votes in the opposite direction of the other two or is divided on the vote $(<.60$ in one direction). Consensual roll-call votes are excluded. The variety of coalitions is an indicator of strategic coalition making, while success rates measure agenda-setting success on the floor.

\section{Roll rates}

Party rolls are tabulated to determine the agenda setter. A roll will be recorded if a majority of party members vote against a bill, but it passes anyway. The roll rates for each party will then be compared to assess whether a U-shaped curve exists. A U-shaped distribution of rolls suggests the median party sets the agenda through ad hoc coalitions with parties to its left and right. A skewed distribution of rolls suggests an enduring coalition. A roll-rate of five percent or less identifies the agenda setters. When combined with the relative location of the agenda-setting party on the WNOMINATE spectrum, we get a picture of the strategic, programmatic positioning of that party.

A final methodological consideration concerns the types of roll-call votes measured. Cox and McCubbins (2005) only considered final passage votes for calculating rolls in the U.S. House of Representatives. This will not work for the Mexican Chamber of Deputies. A bill reported to the floor is first voted on as reported. Following that vote, amendments are debated and voted on. The final bill is passed as amended without any further votes. The amendments are often more divisive and consequential than the reported bill. There are no roll-call votes on the rules. Consequently, all roll-call votes are included in the database. 
Coalitions and agenda-setting in Mexico

\section{Congress (1997-2000)}

The Partido Revolucionario Institucional (PRI) set the legislative agenda during its long rule as the hegemonic party from 1929 to 1997 . With the congressional election of 1997, the PRI lost its majority in the Chamber. The party had not yet adjusted to the new coalitional reality of legislative politics. The PRI lost control of the agenda in the Chamber of Deputies during the LVII Congress as illustrated by its 32 rolls despite holding a large plurality of the seats (see Table 01). Yet the PRI continued its tradition of strong party unity on the floor with a WRice score of .944, somewhat better than its two major rivals, the PAN and the PRD (see Figure 01). The WNOMINATE Coordinates plot (not shown) locates the PRI right of all the other parties in the Chamber on a single significant dimension. The question of democratization largely defined this dimension, with the opposition parties (the PRI still controlled the Senate and the Presidency) challenging the PRI. The PRI and the PRD, who was rolled only 15 times, formed the most coalitions (65). There were 41 PRD_PAN coalitions opposing the PRI on the floor. During the first fragmented congress of the new democratic era in Mexico, no faction in the Chamber of Deputies set the agenda.

\section{Congress (2000-2003)}

The PRI quickly learned how to regain and maintain legislative power starting with the LVIII Congress, but it also struggled to maintain its past levels of party unity as the long-existing divisions between traditional statists and modernizing liberals came to the fore when the Party lost the presidency. The party's bylaws were modified in 2001 to reassert its commitment to "revolutionary nationalism" after the three previous PRI presidents advanced an agenda of economic liberalization (see CRESPO, 2004, p. 77). As President Fox and the PAN attempted to advance liberalizing structural reforms, the PRI was divided over these reforms. PRI legislative leaders programmatically positioned the party as the median faction on the first dimension driven by the question of economic liberalization. In doing so, they negotiated ad hoc coalitions with both the PAN and the PRD. 
Table 01. Rolls and seat counts (1998-2016)

\begin{tabular}{cccccccc}
\hline & LVII & LVIII & LIX & LX & LXI & LXII & LXIII \\
Congress & $1997-$ & $2000-$ & $2003-$ & $2006-$ & $2009-$ & $2012-$ & $2015-$ \\
& 2000 & 2003 & 2006 & 2009 & 2012 & 2015 & 2018 \\
& $\mathrm{~N}=299$ & $\mathrm{~N}=317$ & $\mathrm{~N}=704$ & $\mathrm{~N}=465$ & $\mathrm{~N}=667$ & $\mathrm{~N}=715$ & $\mathrm{~N}=305$ \\
Party & & & & & & & \\
\hline PRI & $32(239)$ & $4(208)$ & $7(211)$ & $0(105)$ & $0(228)$ & $0(211)$ & $0(205)$ \\
PAN & $74(121)$ & $8(202)$ & $48(150)$ & $5(205)$ & $23(142)$ & $39(113)$ & $7(109)$ \\
PRD & $15(125)$ & $29(56)$ & $73(97)$ & $59(127)$ & $66(70)$ & $88(100)$ & $25(60)$ \\
\hline
\end{tabular}

Source: Roll-call data gathered from the Gaceta Parlamentaria available on the Cámera de Diputados website (gaceta.diputados.gob.mx).

Note: Number refers to the total number of rolls in each legislature per party. The number of seats held by each party are in parentheses. Seat numbers are an average of the party seats for the first and last roll-call votes of the congress. Data for LXIII Congress includes only sessions through 2016.

Figure 01. Party unit by Congress (1998-2016)

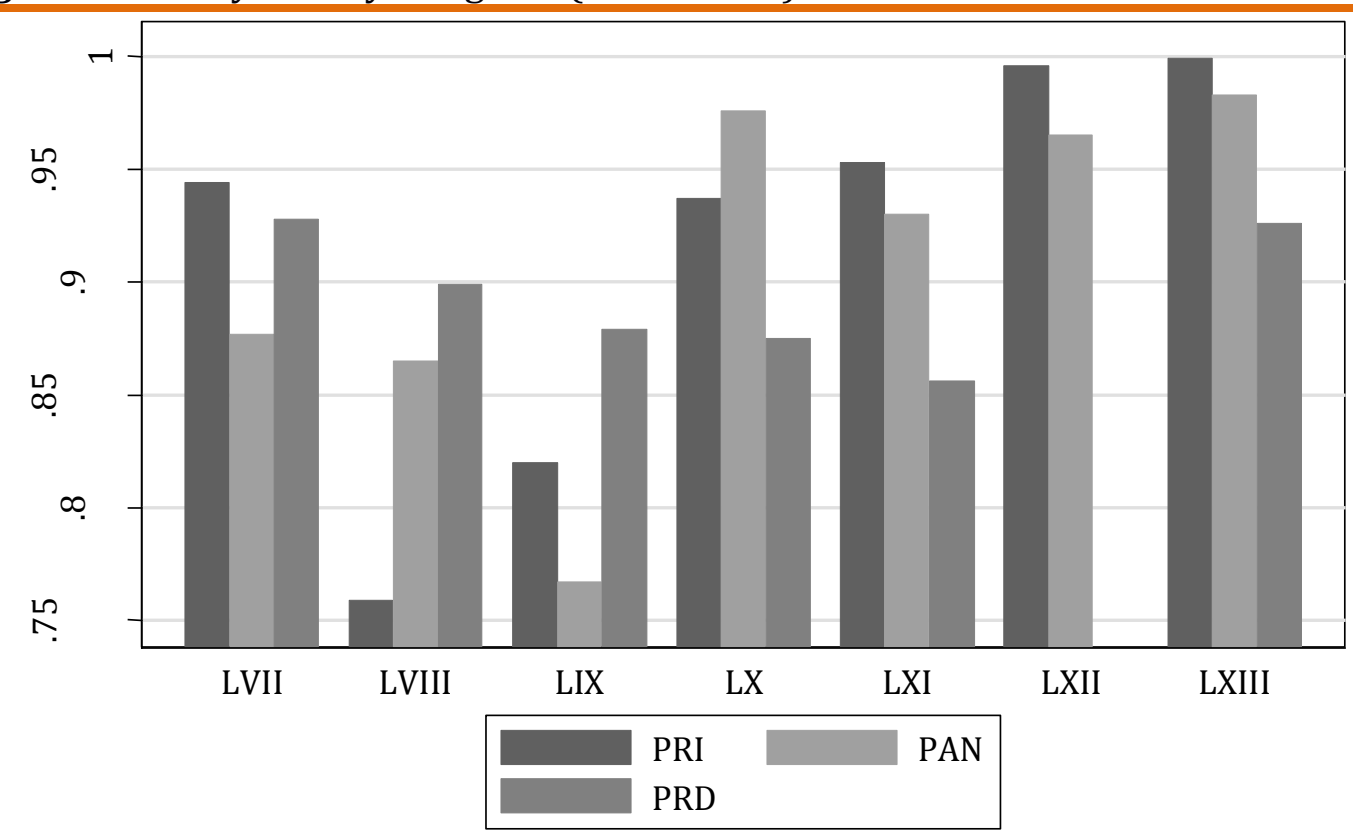

Source: Roll-call data gathered from the Gaceta Parlamentaria available on the Cámera de Diputados website (gaceta.diputados.gob.mx

Despite the PAN's considerably greater seat count than the PRD, there were 18 PRI_PRD coalitions compared to 34 PRI_PAN coalitions in the Chamber during the LVIII Congress. The divisions within the PRI had a substantial negative effect on the PRI's WRice unity score, which fell to .759, lower than either the PRD or the PAN. However, switching between left-leaning (PRI_PRD) and right leaning (PRI_PAN) coalitions probably minimized the negative effect of internal divisions on floor-voting party unity. If PRI leadership had favored only the left 
or right, one faction of the party would have been alienated. The PRI's pivotal role as the first-dimension median party allowed it to keep the number of rolls to only four (05\% of contentious roll-call votes), slightly less than the PAN (08) and considerably less than the PRD (29). Only one of those four rolls occurred on a second-dimension roll-call vote, even though the PRI was located to the right of the other two major parties on this dimension. The PAN and the PRD formed 04 coalitions during this Congress in opposition to the PRI, of which only 01 was affirmative. The PRI was rolled on that occasion. The other three rolls occurred when the PRI formed negative coalitions with the PRD, who had significantly less seats than either the PRI or the PAN.

\section{Congress (2003-2006)}

The PRI's internal divisions between traditionalists and modernizers irrupted on the floor during the LIX Congress (2003-2006) over the issue of extending the scope of the value-added tax (IVA) to food and medicines ${ }^{8}$. A leadership fight between the PRI's Chamber Coordinator (Gordillo) and the Party's national president (Madrazo) made it impossible to keep the divisions behind closed doors (see CRESPO, 2004; GRAYSON, 2003; PECHO MÉNDEZ, 2009). The IVA vote itself was not a roll for the PRI since a slight majority of PRI deputies opposed their legislative leader to help defeat the measure on the floor. Gordillo was replaced and a group of 'priístas' later split off to form a new party, 'Nueva Alianza' (PNA). Despite or perhaps because the intraparty division came to the fore, PRI party unity improved somewhat during this congress. The PRI's WRice score (.820) was between the PAN (.767) and the PRD (.879). The PRI's rolls decreased to 04 percent of contentious roll-call votes (07 rolls), while the PAN (48) and the PRD (97) increased dramatically. Again, the PRI positioned itself as the median party on the first dimension, while the second dimension was no longer significant. As with the previous congress, the PRI formed coalitions with both the PAN (66) and the PRD (46). There were only 10 majority coalitions that excluded the PRI, on half of which the PRI took a negative position. Four of the PRI's rolls resulted from the 05 affirmative coalitions that excluded the PRI

8 Characterizing the PRI's division on this vote as between modernizers and traditionalists is too simplistic, but nevertheless accurate to a degree. 
and included the PAN, the PRD, and one or more of the minor parties (a PAN_PRD coalition was 04 seats shy of a majority). While the PRI's control of the agenda during the Fox 'sexenio' was tenuous, the party was successful in setting the agenda despite significant internal divisions reflected in substantially lower levels of floor-voting party unity compared to previous and subsequent congresses.

\section{Congress (2006-2009)}

Starting with the Calderón 'sexenio', the PRI came to set the legislative agenda without exception. The reader should refer to Figures 01 through $03^{9}$, as well as Table $02^{10}$, as we analyze the four congresses (LX-LXIII) that started just before the inauguration of President Calderón in the Fall of 2006. The PRI has not been rolled even once in the Chamber since the LIX Congress. During the two congresses of the Calderón 'sexenio' (LX-LXI), the PRI positioned itself as the median party on the first dimension between the PRD on the left and the PAN on the right (Figure 03). Its party unity scores improved considerably, rising to .937 during the LX Congress (2006-2009) and .953 during the LXI Congress (20092012). Ninety-one percent of coalitions in the Chamber during the LX Congress were PRI_PAN ones. It is not surprising that the PAN was rolled only 05 percent of the time on contentious roll-call votes. This suggests that there was a PRI_PAN enduring coalition during the LX Congress.

\footnotetext{
${ }^{9}$ Note on Figure 03 that each bar represents the median voter of the labelled party. To read a party's median legislator position relative to the chamber's median legislator, note that the center of bar represents the party's median member. Bar placements are relative to the other parties' median legislators. The distance between parties and the variance within parties cannot be measured due to the very high levels of party unity. Thus, these graphs do not indicate absolute locations. Bars represent the percent of rolls for all contentious roll-call votes for each dimension separately when the second dimension is significant.

10 In Table 02, coalitions are determined as follows: one of the three largest parties (PRI, PAN, PRD) votes in the opposite direction as the other two or one of these parties is divided on the roll-call vote ( $<.60$ voting in the same direction). Thus, consensual roll-call votes are excluded. Only parties necessary to meet a majority seat count are included, starting with the largest seat count and working down until there is a minimum winning coalition per seat counts. Excess parties with less seats may or may not have voted with the coalition.
} 
The PRI did not have the option of forming a majority coalition with only the PRD given that the PRI's voting strength had dropped to only 105 seats, and the PRD had improved its voting strength to only 127 seats. To form a majority coalition, the PRI and PRD had to include the PVEM and 'Convergencia' (CONV) in their coalition. Still, nine percent of the coalitions consisted of these four parties. The PAN and PRD could have formed a majority coalition, but did not do so. Certainly, the ideological divide between the two parties along with the bitterly contested 2006 presidential election made such a coalition unattractive despite previous cooperation between these two parties in opposition to the PRI. Consequently, all majority coalitions in the Chamber during this Congress included the PRI. The PAN also had the option of forming majority coalitions with two different combinations of minor parties; a four-party coalition and a fiveparty coalition. Both possible multiparty coalitions excluding both the PRD and the PRI would have encompassed minor parties on the left and right. With the PRI positioning itself in the center of the programmatic spectrum as illustrated in the WNOMINATE Coordinates plot (Figure 02), these potential coalitions did not materialize.

The first congress of the Calderón 'sexenio' saw policy move to the right on the programmatic spectrum. Seventy-three (73.3) percent of the contentious roll-call votes had a positive coefficient when regressing vote choice on ideal points. The fact that President Calderón sought to enact an agenda of liberalizing reforms probably made the PAN the more attractive coalition partner for the PRI's leadership. Still, the PRI's median legislator was slightly left of the Chamber's median legislator as shown in the Party Rolls bar chart (Figure 03). The fact that the overwhelming number of majority coalitions were PRI_PAN ones, as well as the considerably larger seat count of the PAN (205) compared to the PRI, allowed the PRI to hold the median location while public policy moved right. 
Figure 02. WNOMINATE Coordinates Plots (2006-2016)

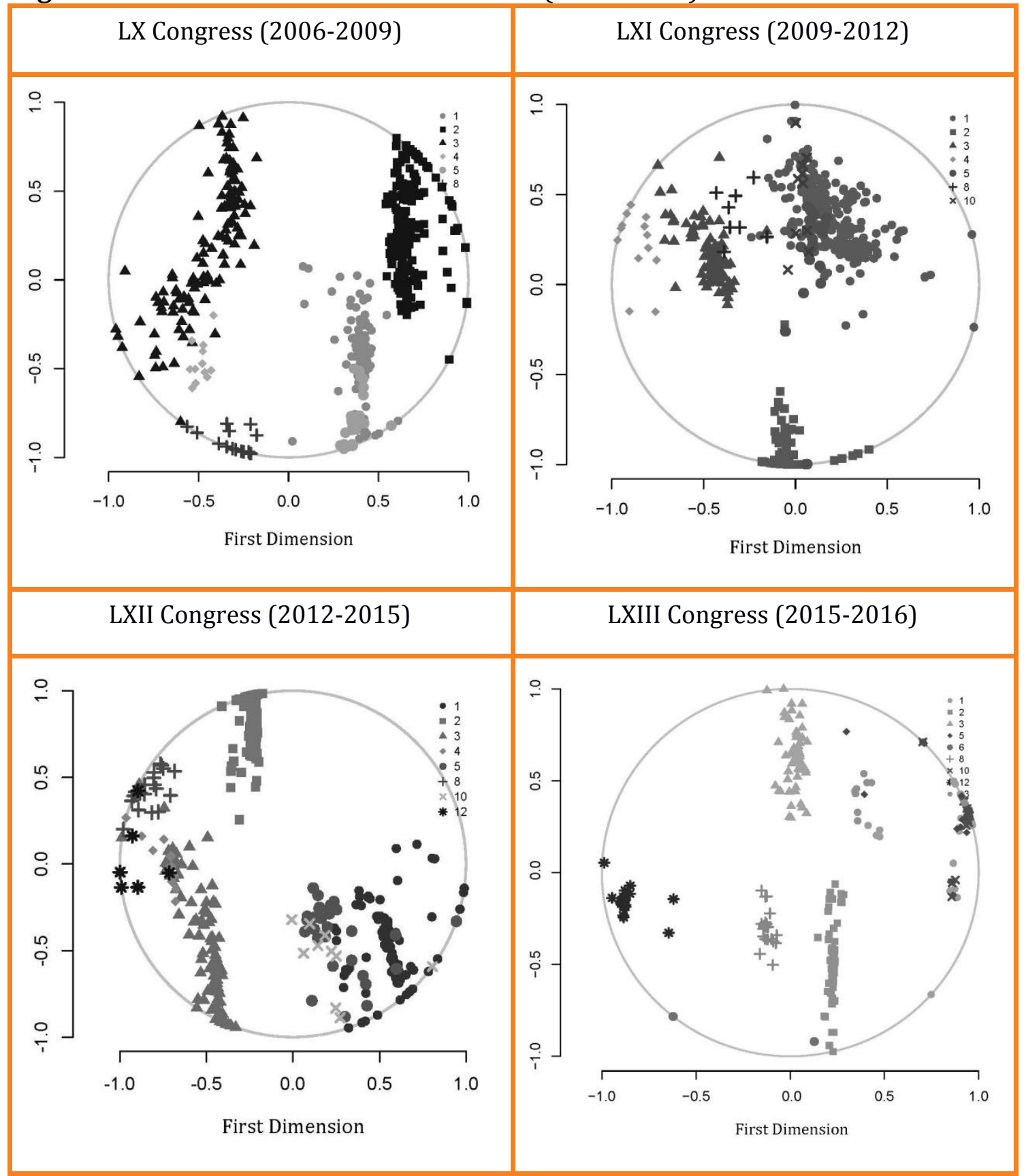

Source: Roll-call data gathered from the Gaceta Parlamentaria available on the Cámera de Diputados website (gaceta.diputados.gob.mx).

Notes: PRI $=1, \mathrm{PAN}=2, \mathrm{PRD}=3, \mathrm{PT}=4, \mathrm{PVEM}=5$, Convergenica $/ \mathrm{MC}=8, \mathrm{PNA}=10, \mathrm{MRN}=12$, $\mathrm{PES}=13$. Note that the Second Dimension is only significant for the LXI and LXII Congresses (Scree Plots not shown). LX: N=136 (329 deleted); Predicted Yeas 98.9\%; Predicated Nays 95.8\%; Correction classification 97.65\%, 97.92\%; APRE 0.889, 0.902. LXI: N=236 (431 deleted); Predicted Yeas 98.3\%; Predicated Nays 92.7\%; Correction classification 94.84\%, 96.06\%; APRE 0.638, 0.794. LXII: N=301 (414 deleted); Predicted Yeas 98.6\%; Predicated Nays 92.8\%; Correction classification 95.04\%, 97.32\%; APRE 0.757, 0.868. LXIII: N=86 (219 deleted); Predicted Yeas 99.7\%; Predicted Nays 97.2\%; Correct classification 98.38\%, 99.28\%; APRE 0.907, 0.958 
Table 02. Majority coalition frequencies and success rates for contentious roll-call votes (2006-2016)

\begin{tabular}{|c|c|c|c|c|}
\hline \multirow[t]{2}{*}{ Congress/Coalition } & \multicolumn{4}{|c|}{ Number of Coalitions } \\
\hline & LX & LXI & LXII & LXIII \\
\hline PRI_PAN & 92 & 91 & 80 & 21 \\
\hline PRI_PRD & $\mathrm{n} / \mathrm{a}^{*}$ & 19 & 28 & 3 \\
\hline PRI_PVEM & $\mathrm{n} / \mathrm{a}^{*}$ & 18 & $\mathrm{n} / \mathrm{a}^{*}$ & $\mathrm{n} / \mathrm{a}^{*}$ \\
\hline PRI_PT & $\mathrm{n} / \mathrm{a}^{*}$ & 2 & $\mathrm{n} / \mathrm{a}^{*}$ & $\mathrm{n} / \mathrm{a}^{*}$ \\
\hline PRI_PVEM_PNA & $\mathrm{n} / \mathrm{a}^{*}$ & $\mathrm{n} / \mathrm{a}^{* *}$ & 30 & 4 \\
\hline PRI_PRD_PVEM_CONV & 9 & $\mathrm{n} / \mathrm{a}^{* *}$ & $\mathrm{n} / \mathrm{a}^{* *}$ & $\mathrm{n} / \mathrm{a}^{* *}$ \\
\hline PAN_PRD & 0 & $n / a^{*}$ & $\mathrm{n} / \mathrm{a}^{*}$ & $n / a^{*}$ \\
\hline PAN_PRD_PVEM & $\mathrm{n} / \mathrm{a}^{* *}$ & $\mathrm{n} / \mathrm{a}^{*}$ & 1 & $\mathrm{n} / \mathrm{a}^{*}$ \\
\hline PAN_PRD_PVEM_PT_MC & $\mathrm{n} / \mathrm{a}^{* *}$ & 1 & $\mathrm{n} / \mathrm{a}^{* *}$ & $\mathrm{n} / \mathrm{a}^{* * * *}$ \\
\hline PAN_PRD_PVEM_MRN_MC & $\mathrm{n} / \mathrm{a}^{* * * *}$ & $\mathrm{n} / \mathrm{a}^{* * * *}$ & $\mathrm{n} / \mathrm{a}^{* * * *}$ & 0 \\
\hline PAN_PRD_PVEM_MC_PNA_PES & $\mathrm{n} / \mathrm{a}^{* * * *}$ & $\mathrm{n} / \mathrm{a}^{* * * *}$ & $\mathrm{n} / \mathrm{a}^{* * * *}$ & 0 \\
\hline \multirow[t]{2}{*}{ Total } & 101 & 131 & 139 & 28 \\
\hline & \multicolumn{4}{|c|}{ Percentage of Total } \\
\hline PRI_PAN & 91,1 & 69,5 & 57,6 & 75 \\
\hline PRI_PRD & & 14,5 & 20,1 & 10,7 \\
\hline PRI_PVEM & & 13,7 & & \\
\hline PRI_PT & & 1,5 & & \\
\hline PRI_PVEM_PNA & & & 21,6 & 14,3 \\
\hline PRI_PRD_PVEM_CONV & 8,9 & & & \\
\hline PAN_PRD & 0 & & & \\
\hline PAN_PRD_PVEM & & & 0,7 & \\
\hline PAN_PRD_PVEM_PT_MC & & 0,8 & & \\
\hline PAN_PRD_PVEM_MRN_MC & & & & 0 \\
\hline PAN_PRD_PVEM_MC_PNA_PES & & & & 0 \\
\hline \multirow[t]{2}{*}{ Total } & 100 & 100 & 100 & 100 \\
\hline & \multicolumn{4}{|c|}{ Percentage of Success } \\
\hline PRI_PAN & 100 & 100 & 100 & 100 \\
\hline PRI_PRD & & 100 & 100 & 100 \\
\hline PRI_PVEM & & 88,9 & 100 & \\
\hline PRI_PT & & 100 & & \\
\hline PRI_PVEM_PNA & & & 96,6 & 100 \\
\hline PRI_PRD_PVEM_CONV & 100 & & & \\
\hline PAN_PRD & & & & \\
\hline PAN_PRD_PVEM & & & 0 & \\
\hline PAN_PRD_PVEM_PT_MC & & 0 & & \\
\hline PAN_PRD_PVEM_MRN_MC & & & & \\
\hline PAN_PRD_PVEM_MC_PNA_PES & & & & \\
\hline
\end{tabular}

Source: Roll-call data gathered from the Gaceta Parlamentaria available on the Cámera de Diputados website (gaceta.diputados.gob.mx).

Notes: * not a potential coalition due to insufficient seats; ${ }^{* *}$ not a minimum-winning coalition due to excess seats (does not indicate whether minor parties joined the coalition); ${ }^{* * *}$ CONV changed its name to MC in the LXI Congress; MC is only used to designate the party in the LXII Congress; **** One of the parties were not in this Congress.

Partido Revolucionario Institucional (PRI); Partido Acción Nacional (PAN); Partido Revolucionario Democratica (PRD); Partido Verde Ecologista Mexicana (PVEM); Partido Trabajadores (PT); Partido Nueva Allianza (PNA); Convergencia/Movimiento Ciudadano (CONV/MC); Movimiento Regeneración Nacional (MNR- commonly known as Morena); Partido Encuentro Social (PES).

Data for the LXIII Congress includes roll-call votes through the third regular session or midway through the congress. 
Despite the rightward direction of public policy under the Calderón presidency, the PAN and its co-partisan executive were largely frustrated in their efforts to enact the structural reforms they sought. Instead, the median position of the PRI, as the essential coalition partner for the PAN, resulted in only quite modest reforms. The PRI was still not ready to support extensive structural reforms. Doing so would likely have fractured the PRI in the Chamber, resulting in rolls on the floor. Despite having considerably less seats than the PAN, the PRI set the agenda as evinced by its zero roll-rate verses the PAN's 05 percent roll-rate.

\section{Congress (2009-2012)}

The patterns of coalition formation became more complex during the second congress of the Calderón 'sexenio'. Not only were there more combinations of parties forming floor-voting coalitions in the LXI Congress, but a second dimension also emerged. While the PRI continued as the median party on the first dimension, the median PRI legislator was right of the Chamber's median legislator. On the second dimension, the party was on the far right of the programmatic spectrum (Figure 03). All majority coalitions on both dimensions included the PRI. The PRI did quite well in the 2009 midterm election, increasing its seat count to 228 in the LXI Congress, only 23 seats shy of a majority. Both the PAN's and PRD's seat counts fell dramatically. This context gave the PRI more options and leverage to form coalitions. The PAN and PRD together only had one five-party potential coalition with the PVEM, the Partido Trabajadores (PT), and the Movimiento Ciudadano (MC), which was never realized. While 70 percent of the PRI's coalitions were still formed with the PAN, the PRI formed 15 percent of its coalitions with the PRD. But the PRI also had the option in this congress to form majority coalitions with minor parties. The most prevalent minor-party coalition was with the PVEM $(14 \%)$.

There were three main types of coalitions in the LXI Congress. First, PRI_PAN coalitions formed the first dimension. These were usually joined by the PVEM and the PNA, while the PRD, the PT, and the MC were on the losing side. But there was also a second-dimension coalition flowing from PRI_PRD coalitions in which all the minor parties joined. As shown in the WNOMINATE coordinates plot (Figure 02), it was the PAN against the rest of the parties on this dimension. For 
the 18 floor-votes in which neither the PRD nor the PAN voted with the PRI, a third type of majority coalition formed; namely, a PRI_PVEM coalition. The PRI's median legislator can be located to the right of the chamber median on the first two dimensions, and probably on the third one too. Still, the PRI's median legislator is closer to the Chamber median than any other party's median legislator on the first dimension. On the second dimension, the PRI's median legislator is furthest from the Chamber median compared to other parties (Figure 03).

The PAN was only rolled once on first-dimension roll-call votes, while it was rolled 20 times on second-dimension votes. For the first dimension, there existed an enduring PRI_PAN coalition with the PRI as the median party. One might conclude that the PRI and the PAN jointly set the first-dimension agenda. However, the PRI turned to the PRD and/or the PVEM when necessary, resulting in numerous rolls for the PAN. Furthermore, policy moved to the right while the PAN was left of the Chamber median on both dimensions. It moved toward the PRI, whose median legislator was right of the Chamber median. Seventy-one percent of all roll-call votes had a positive coefficient. This pattern of creative coalitionmaking helped the PRI improved its WRice score to .953 during the LXI Congress. Most importantly, we see evidence of the strategic flexibility of the PRI to position itself programmatically to avoid rolls and move policy in its preferred direction, which was increasingly toward the right.

During the Calderón 'sexenio', the PRI moved from setting the agenda through ad hoc coalitions as the pivotal median party to forming enduring coalitions. During the LX Congress, the party continued to form coalitions as the median party. Given the changed context in respect to seat shares, the PRI and the PAN developed an enduring coalition, but for reasons discussed above, the PRI can be considered the agenda setter for this coalition. The bar charts for party rolls (Figure 03) during the LXI Congress suggest that the PRI developed a more complex strategy, aided by its improved voting strength in the Chamber relative to the PAN and the PRD, and by the growing voting strength of minor parties. On the first dimension, all parties in PRI coalitions that included the PAN and usually the PVEM and PNA had very low roll-rates, while roll-rates were quite high for the PRD, the PT, and the MC. The first-dimension parties of the left were frequently rolled, while center and right parties, including the PRI, were rarely rolled. 
Figure 03. Party rolls by Congress and dimension (2006-2016)
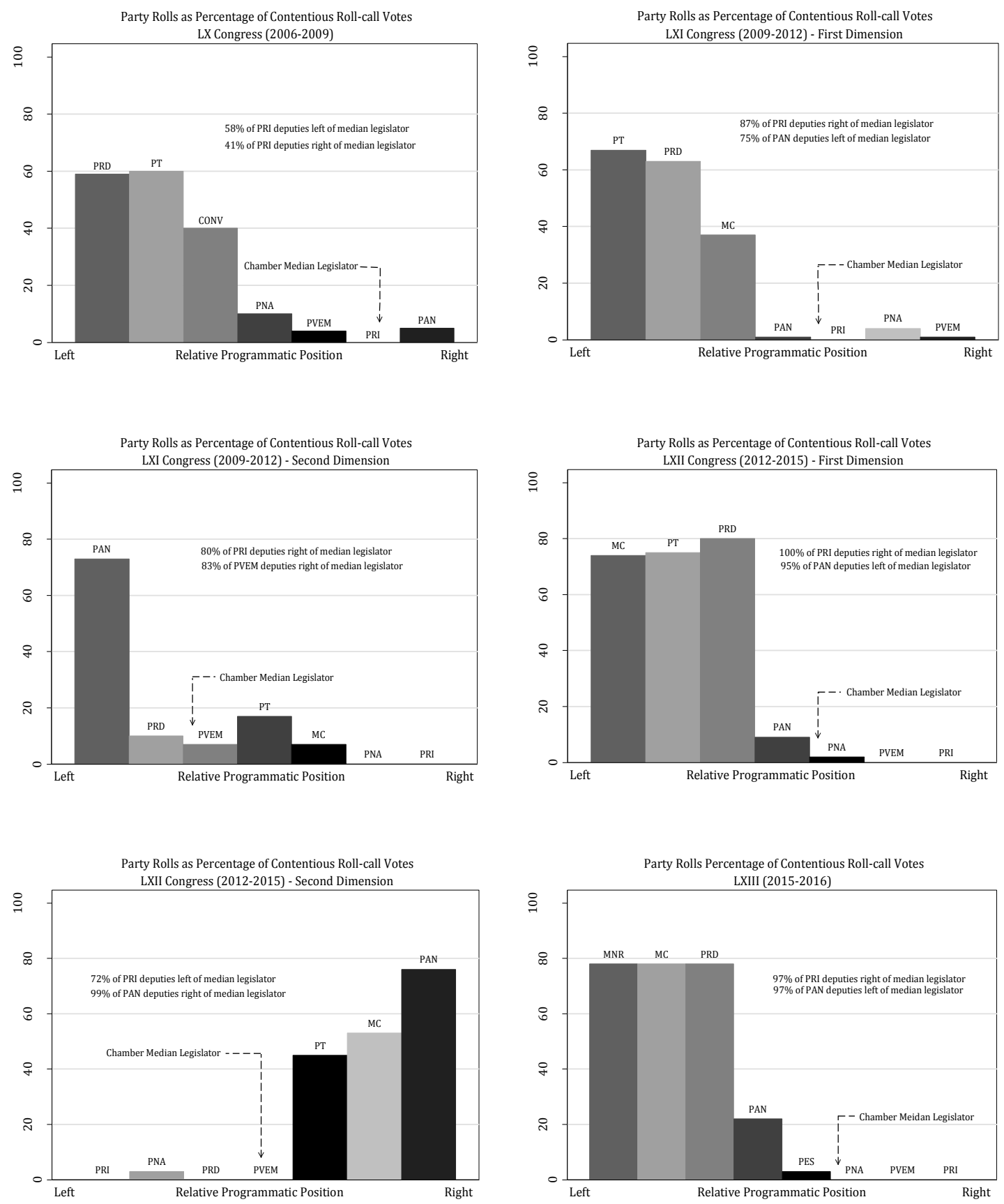

Source: Roll-call data gathered from the Gaceta Parlamentaria available on the Cámera de Diputados website (gaceta.diputados.gob.mx).

We see a similar pattern for the second dimension, but with a different combination of parties. The PRD and all the other parties that allied with the PRI were rolled infrequently, while the PAN was rolled numerous times. When the PRI and PVEM opposed the rest of the parties, they were never rolled and only lost on 
two roll-call votes they supported. In sum, the PRI successfully used the median party strategy when needed to form majority coalitions with the PAN, but it was also able to form successful coalitions with minor parties as the party furthest from the median legislator.

\section{Congress (2012-2015)}

The return of the PRI to the presidency during the Peña Nieto 'sexenio' saw the PRI faction in the Chamber of Deputies leaving behind the median-party strategy. The party moved away from the center on the first-dimension programmatic spectrum (Figure 03) as President Peña Nieto embraced the 'Pacto por México', which was negotiated by the three major parties outside of the legislative process before he took office. As with the three liberalizing PRI presidencies of the 1980s and 1990s, PRI legislators loyally supported their president. The PAN had long sought structural reforms, so the PRI could rely on their support for a structural reform agenda legitimized by the 'Pacto' (LAWSON, 2015, p. 40). However, the PRI did not need the PAN or the PRD to pass reforms in the Chamber. It had the support of its by now enduring coalition partners, the PVEM and PNA. Together, the PRI and its two loyalist parties constituted a majority in the LXII Congress. The PRD was also a potential coalition partner. The party was an important participant in the 'Pacto', though the result was the eventual exit of their former presidential candidate, Lopez Obrador (AMLO), and the fracturing of the PRD. Nevertheless, most PRD legislators supported many of the floor-votes that made up the structural reforms enacted during this congress. While the PRD's party unity suffered, both the PRI and the PAN improved their unity scores. The PRI exhibited near perfect floor-voting unity (.996).

The ability of the PRI to legislate the 'Pacto's' reform agenda with only the support of the PVEM and PNA, who had voted with the PRI on virtually all bills during the previous two congresses, meant that the PAN and the PRD found themselves opposing Peña Nieto's proposals at times. Often, only the PRD or the PAN would support the PRI's legislative program. The result was an interesting pattern of party locations along the two dimensions of the policy spectrum as can be seen in the WNOMINATE coordinates plot for the LXII Congress (Figure 02). Both dimensions were significant. The PRI is located on the right side of the first 
dimension along with the PVEM and the PNA, while the PRD and other left of center parties are located on the left as we would expect. The left-of-median position of the PAN along this dimension driven by economic liberalization is interesting. We should not necessarily conclude that the PRI now holds an economic policy stance to the right of the PAN. After all, Peña Nieto's structural reforms enacted the policies long sought by the PAN. It is more likely that the PAN found itself voting against the PRI because of differences over the specifics of structural reforms. For example, during the fall of 2013 the PAN strongly objected to the equalization of IVA rates that would negatively affect its base in the northern part of the country. It voted against this part of the fiscal reform package, but was rolled by the PRI and the PRD ${ }^{11}$.

Because of the PRI's ability to legislate without the PAN or the PRD, these potential coalition partners experienced considerable rolls during the LXII Congress. Given that the PRD was divided over structural reforms, it is not surprising that it had more than twice as many rolls as the PAN. The PAN was rolled 39 times, 10 of which were on first-dimension votes. These 10 rolls resulted from PRI_PVEM_PNA coalitions. The PAN had the option of a coalition with the PRD and the PVEM, excluding the PRI, but only a single unsuccessful one was formed. Despite suffering so many rolls, the PAN formed successful majority coalitions with the PRI 80 times (57\% of all coalitions).

There was a second dimension of coalitional voting during the first congress of the Peña Nieto presidency. The PRI coalitions in this dimension included the PRD, and are consequently located on the left of the programmatic spectrum as shown in the WNOMINATE Coordinates plot (Figure 02). They also included the PRI's faithful minor-party coalition partners, the PNA and the PVEM. Unlike the PAN who was rolled numerous times on both dimensions, the PRD was rolled only once on the second dimension. Curiously, the other parties on the firstdimension left voted with the PAN on most second-dimension roll-call votes. Clearly, we cannot view the issues behind these votes in terms of first-dimension left-right issues. What we can conclude is that the PRI allied with either the PAN or the PRD when it served its purposes. When necessary, the PRI simply relied on the

11 See fourth floor-vote in Chamber on October 17th, 2013, accessible at <gaceta.diputados.gob.mx>. 
PVEM and the PNA to win floor votes. But the PAN and the PRD had the potential to defeat the PRI on the floor if it could win over either of these two minor parties. Given how many times these major parties were rolled, an interesting question is why the PAN and the PRD did not do so. Perhaps it was due to programmatic differences, but such differences did not prevent cooperation in the past. Nonprogrammatic benefits provided by the PRI to their junior partners may have discouraged these potential coalitions. However, presidential resources would not appear to be the source of the PVEM's and PNA's loyalty to the PRI given that we saw this pattern under both the Calderón and Peña Nieto 'sexenios'. There was one PRD_PAN_PVEM majority coalition during the LXII Congress, but it was defeated.

\section{Congress (2015-2018)}

The LXIII Congress continued the coalitional patterns of the LXII Congress, but with less PRI_PRD coalitions. The PRD's unity score improved dramatically once the followers of AMLO had left the party and the Movimiento Regeneración Nacional (MRN) had elected its own members to the Chamber. Despite the PRD becoming a more reliable partner, albeit with reduced seats, only 03 PRI_PRD coalitions $(11 \%)$ were formed as of half way through the congress. The PRI continues to form coalitions mostly with the PAN, but has relied four times (14\%) on the PVEM and PNA to win floor votes in opposition to both the PAN and the PRD. WRice scores have reached near perfect unity for the PRI and the PAN. A second dimension may still become significant as more roll-call votes are recorded, but so far coalitions are sorting out along the first-dimension. Since the PAN continues to be rolled frequently (22\% of contentious votes in this congress), one can infer that the PRI is able to move the PAN toward its policy preferences when PRI_PAN coalitions are formed. While the PAN and the PRD together have had two options to form coalitions with minor parties, they have not done so. Policy has moved to the right with 90.6 percent of the coefficients being positive compared to 75.2 percent of the coefficients in the LXII Congress. This is so even though the PAN's median legislator is left of the Chamber median (Figure 03). While coalitions between the PAN and the PRI were most prevalent, the PRI has set the agenda and the direction of policy with the help of its two minor-party partners. 


\section{Why the PRI has been the agenda setter}

The PRI has set the Chamber's legislative agenda since 2000 even though it was not the median party in four of the seven congresses over both dimensions of vote choice. During the Peña Nieto 'sexenio', it has not been the median party on the first dimension. Rolls clearly did not form U-shaped patterns as would be the case without enduring coalitions. Despite opportunities to form majority coalitions excluding the PRI, only two unsuccessful ones were formed since 2006. Policy preferences do appear to have constrained coalition formation.

Programmatic constraints among the PRI's major opponents aided the PRI. In contrast, the PRI positioned itself as the median party or as a party on the right of the programmatic spectrum as needed. The PRI, as the median party, formed ad hoc coalitions with the PAN or the PRD along the first dimension during the Fox presidency. Starting with the Calderón presidency, the PRI established more enduring coalitions. During the first congress of his presidency, an enduring coalition with the PAN was evident. When the context changed during the second congress under Calderón, the PRI formed more coalitions with other parties. The party favored the PAN most often, forming the first dimension, but turned toward the PRD or the PVEM, creating other dimensions. Once the PRI regained the presidency, it continued to set the agenda. By the Peña Nieto 'sexenio' (20122018), the party's median legislator was located further to the right than any party on the first dimension.

PRI deputies during the Peña Nieto 'sexenio' have faithfully supported their president's legislative agenda. Party unity has been essential to the PRI's ability to set the agenda. Party leaders have strategically selected partners to avoid rolls and maximized success on the floor, resulting in rolls and defeats for other parties that could have formed majority coalitions. The potential existed for the PAN to set the agenda, though only in the LVIII and LX Chambers did the PAN have a non-PRI two-party majority coalition option. The PRI was better at playing the coalitional game, or more willing to do so. This pattern persisted whether the presidency was held by the PAN or the PRI.

The PRI has set the agenda since 2000 because of its strategic capabilities, strong party unity, and emphasis on success. These characteristics have given the PRI the programmatic flexibility needed to set the agenda. It has done so without 
favorable rules, and at times without even a plurality of seats or a co-partisan executive. Majoritarian gatekeeping combined with rules empowering party leadership have allowed the PRI to strategically set the agenda. This case study of legislative agenda-setting supports the argument that legislative institutions need 'not' empower agenda-setting parties in fragmented, majoritarian congresses, nor are executive-led parliamentary coalitions necessary.

\section{Conclusion}

The analysis presented here confirms the importance of institutions for agenda-setting in fragmented legislative assemblies. However, legislative behavior in the Mexican Chamber of Deputies cannot be explained by institutional constraints alone. When a single legislative party consistently sets the agenda over many congresses despite changing contexts, and under the same majoritarian rules, we need to search elsewhere for an explanation. Strategy plays an important role in coalition-formation and agenda-setting. One legislative faction may be more capable and willing to employ strategic positioning, thus forming coalitions on its own terms. The programmatic flexibility of that party is central to an explanation of agenda-setting grounded in strategic capacity.

The foregoing analysis of agenda control in the Mexican Chamber of Deputies supports the hypothesis advanced in this study that the most programmatically flexible party will set the agenda under majoritarian gatekeeping rules in a fragmented congress given sufficient unity. More studies are needed to better understand the role of strategy in coalition formation and agendasetting. Perhaps the Mexican case is 'sui generis'. But even if it is, institutions and other contextual factors are not determinative. Strategy plays a role in legislative politics. The Mexican case illustrates the need to incorporate the strategic behavior of parties into our theories of agenda-setting for fragmented legislative assemblies in presidential regimes.

Submitted on June 02, 2017. Accepted on December 21, 2017. 


\section{References}

ALARCÓN OLGUÍN, Víctor (2009), El Poder Legislativo en México: evolución y tendencias en el contexto de la democratización. In: Treinta Años de Cambios Políticos en México. Edited by ATTILI, Antonella. Mexico: Porrúa. pp. 187-209.

ALDRICH, John H. and ROHDE, David W. (2001), The logic of conditional party government: revisiting the electoral connection. In: Congress Reconsidered. Edited by DODD, Lawrence C. and OPPENHEIMER, Bruce I.. Washington: CQ Press. pp. 269-292.

ALEMÁN, E. (2006), Policy gatekeepers in Latin American legislatures. Latin American Politics and Society. Vol. 48, № 03, pp. 125-155.

AMORIM NETO, Octavio; COX, Gary W., and McCUBBINS, Mathew D. (2003), Agenda power in Brazil's Camara Dos Deputados, 1989-98. World Politics. Vol. 55, pp. 550-578.

BÉJAR ALGAZI, Luisa (2006), Los partidos en el Congreso de la Unión: la representación parlamentaria después de la alternancia. México: Ediciones Gernika, S.A. 290 pp..

BRUHN, Kathleen (2015), Chronicle of a victory foretold. In: Mexico's evolving democracy: a comparative study of the 2012 elections. Edited by DOMÍNGUEZ, Jorge I.; GREENE, Kenneth F.; LAWSON, Chappell H., and MORENO, Alejandro. Baltimore: Johns Hopkins University Press. pp. 51-86.

BRUHN, Kathleen (1998), The partido de la revolución democrática: diverging approaches to competition. In: Governing Mexico: political parties and elections. Edited by SERRANO, Monica. London: Institute of Latin American Studies. pp. 114-136.

CALVO, Ernesto (2014), Legislator success in fragmented Congresses in Argentina: plurality cartels, minority presidents, and lawmaking. Cambridge: Cambridge University Press. 232 pp..

CAMP, Roderic Ai (2016), A democratic paradox: more governability, less trust. In: Democracy and its discontents in Latin America. Edited by FOWERAKER, Joe and TREVIZO, Dolores. Boulder: Lynne Rienner Publishers. pp.223-239.

CAMP, Roderic Ai (2013), Peña Nieto's cabinet: what does it tells us about Mexican leadership? Democracy and election series. Washington: Mexico Institute, Woodrow Wilson Center. Paper.

CAMP, Roderic Al (2007), Politics in Mexico: the democratic consolidation. New York: Oxford University Press. 352 pp..

CANTÚ, Francisco and DESPOSATO, Scott (2012), The new federalism of Mexico's party system. Journal of Politics in Latin America. Vol. 04, № 02, pp. 03-38. 
CAREY, John M. (2007), Competing principals, political institutions, and party unity in legislative voting. American Journal of Political Science. Vol. 51, № 01, pp. 92-107.

CARROLL, Royce and POOLE, Keith T. (2014), Roll-call analysis and the study of legislatures. In: The Oxford handbook of legislative studies. Edited by MARTIN, Shane; SAALFELD, Thomas, and STROM, Kaare W.. Oxford: Oxford University Press. pp. 103-125.

COX, Gary W. (2006), The organization of democratic legislatures. In: The Oxford handbook of political economy. Edited by WITTMAN, Donald A., and WEINGAST, Barry R..New York: Oxford University Press. pp. 141-161.

COX, Gary W. and McCUBBINS, Mathew D. (2011), Managing plenary time: the U.S. Congress in comparative Context. In: The Oxford handbook of the American Congress. Edited by EDWARDS III, George C.; LEE, Frances E., and SCHICKLER, Eric. Oxford: Oxford University Press. pp. 451-472.

COX, Gary W. and McCUBBINS, Mathew D. (2005), Setting the agenda: responsible party government in the U.S. house of representatives. Cambridge: Cambridge University Press. 352 pp..

COX, Gary W. and McCUBBINS, Mathew D. (1993), Legislative Leviathan: party government in the house. Berkeley: University of California Press. 289 pp..

CRESPO, José Antonio (2004), Party competition in Mexico: evolution and prospects. In: Dilemmas of political change in Mexico. Edited by MIDDLEBROOK, Kevin J.. London: Institute of Latin American Studies. pp. 5781.

DOMÍNGUEZ, Jorge I. (2015), Mexico's 2012 presidential election: conclusions. In: Mexico's evolving democracy: a comparative study of the 2012 elections. Edited by DOMÍNGUEZ, Jorge I.; GREEN, Kenneth F.; LAWSON, Chappell H., and MORENO, Alejandro. Baltimore: Johns Hopkins University Press. pp. 252-270.

GONZÁLEZ, R. C. $(2007,4 / 15)$. The democratization of agenda control in the Mexican Chamber of Deputies, 2000-2006. Paper delivered at the Midwest Political Science Association. 65th Annual National Conference. Chicago

GRAYSON, George W. (2003), Beyond the mid-term elections: Mexico's political outlook 2003-2006. Available at <http://www.csis.org/americas/mexico/0310_graysson.pdf>. Accessed on March 15, 2012.

HABER, Stephen; KLEIN, Herbert S.; MAURER, Noel, and MIDDLEBROOK, Kevin J. (2008), Mexico since 1980. New York: Cambridge University Press. 266 pp.. 
JONES, Mark P. and HWANG, Wonjae (2005), Party government in presidential democracies: extending cartel theory beyond the U.S. Congress. American Journal of Political Science. Vol. 49, № 02, pp. 267-282.

LANGSTON, Joy K. (2017), Democratization and authoritarian party survival: Mexico's PRI. New York: Oxford University Press. 256 pp..

LAWSON, C. (2015), The 2012 election in context. In: Mexico's evolving democracy: a comparative study of the 2012 elections. Edited by DOMÍNGUEZ, Jorge I.; GREENE, Kenneth F.; LAWSON, Chappell H., and MORENO, Alejandro. Baltimore: Johns Hopkins University Press. pp. 18-50.

LEHOUCQ, Fabrice; NEGRETTO, Gabriel; APARICIO, Francisco; NACIF, Benito, and BENTON, Allysson (2008), Policymaking in Mexico under one-party hegemony and divided government. In: Policymaking in Latin America: how politics shapes policies. Edited by STEIN, Ernesto and TOMMASI, Mariano. Washington: Inter-American Development Bank. pp. 287-328.

LINZ, Juan José (1990), The perils of presidentialism. Journal of Democracy. Vol. 01, № 01, pp. 51-69.

LOAEZA, Soledad (2002), The National Action Party (PAN): from the Fringes of the Political System to the Heart of Change. In: Christian democracy in Latin America: electoral competitions and regime conflicts. Edited by MAINWARING, Scott and SCULLY, Timothy. R.. Stanford: Stanford University Press. pp. 196246.

MIZRAHI, Yemile (2003), From martyrdom to power. Notre Dame: University of Dotre Dame Press. 224 pp..

MOSSIGE, Dag (2013), Mexico's left: the paradox of the PRD. Boulder: First Forum Press. 325 pp..

NACIF, Benito (2002), Understanding party discipline in the Mexican Chamber of Deputies: the centralized party model. In: Legislative politics in Latin America. Edited by MORGENSTERN, Scott and NACIF, Benito. Cambridge: Cambridge University Press. pp. 254-284.

PECHO MÉNDEZ, Guadalupe (2009), El PRI: relación interna de fuerzas y conflicto en la vispera del proceso electoral de 2006. Política y gobierno. Vol. 16, № 01, pp. 157-190.

POOLE, Keith T. (2005), Spatial models of parliamentary voting. Cambridge: Cambridge University Press. 248 pp..

POOLE, Keith T.; LEWIS, Jeffrey B.; LO, James, and CARROLL, Royce (2011), Scaling roll call votes with W-NOMINATE in R. Journal of Statistical Software. Vol. 42, № 14, pp. 01-21. 
POOLE, Keith T. and ROSENTHAL, Howard (1991), Patterns of congressional voting. American Journal of Political Science. Vol. 35, № 01, pp. 228-278.

PRUD'HOMME, Jean-François(2010), The restructuring of the party system in the wake of the 2006 elections. In: Mexico's democratic challenges: politics, government, and society. Edited by SELEE, Andrew and PESCHARD, Jacqueline. Washington: Woodrow Wilson Center Press. pp. 50-67.

SAIEGH, Sebastian M. (2009), Recovering a basic space from elite surveys: evidence from Latin America. Legislative Studies Quarterly. Vol. 34, № 01, pp. 117-145.

WISE, Carol (2003), Mexico's democratic transition: the search for new coalitions. In: Post-stabilization politics in Latin America: competition, transition, collapse. Edited by WISE, Carol and ROETT, Riordan. Washington: Brookings Institution Press. pp. 159-198.

WUHS, Steven T. (2013), Inclusion and its moderating effects on ideas, interests and institutions: Mexico's Partido Acción Nacional. Party Politics. Vol. 19, № 02, pp. 187-209.

WUHS, Steven T. (2001), Barbarians, bureaucrats, and bluebloods: fractional change in the National Action Party. In: Party politics and the struggle for democracy in Mexico: national and state-level analyses of the Partido Acción Nacional. Edited by MIDDLEBROOK, Kevin J.. San Diego: La Jolla, Center for U.S.-Mexican Studies at the University of California. pp. 129-155. 